\title{
Protein Capicua Homolog
}

National Cancer Institute

\section{Source}

National Cancer Institute. Protein Capicua Homolog. NCI Thesaurus. Code C97914.

Protein capicua homolog (1608 aa, $164 \mathrm{kDa}$ ) is encoded by the human CIC gene. This protein is involved in transcriptional regulation. 